\title{
2 Arctic broadband connectivity and the creative economy
}

\author{
Access, challenges, and \\ opportunities in Nunavut \\ and Alaska
}

\section{Timothy J. Pasch and Olaf Kuhlke}

\section{Introduction}

The North American Arctic geographic region is increasingly attracting economic and political interest (Keil \& Knecht, 2017; Smith, 2010). Along with climate change and geostrategic concerns, new business opportunities are emerging, and Arctic stakeholders are playing a key role in facilitating and creating favorable conditions for boosting Arctic economic activity (Petrov, 2017). There is a wide spectrum of Arctic business activities underway, of which oil and gas, mining, and shipping are perhaps among the most well-known.

Beyond extractive and transport-related industries, there is growing interest in the North American Arctic region's human economic potential in areas such as eco-tourism, innovation and entrepreneurship. Indigenousowned, digitally connected culturally related businesses show increasing potential to address specific sustainable opportunities and needs of the region (Dana \& Anderson, 2007; Patvardhan, 1990; Shadian, 2018).

In parallel to these economic trends, the North American Arctic is becoming more digitally connected (Christensen, 2003; Hudson, 2011; Warwick, 2019). Some researchers have argued that in order to succeed, new business development in the North American Arctic must be rooted in its people(s) and grounded in traditional knowledge toward the goal of innovative development, in order that the Arctic's unique resources and human capital become competitive on a global scale (Pasch, 2015; Rodon \& Lévesque, 2015). Rural Arctic communities are under pressure, as younger generations increasingly desire the services, opportunities, and education offered in greater metropolitan areas (Seyfrit, Hamilton, Duncan, \& Grimes, 1998). Arctic business development is, therefore, an existential issue.

This chapter argues that creating economic opportunities of a sufficient size and critical mass, if properly balanced with community informatics and values, has the potential to offer rural and remote Arctic residents aspects of the quality of life they seek while celebrating and leveraging 
traditional knowledge, languages, and lifestyle. New technologies are revising the concept of "remote" and are rendering previously inaccessible projects economically feasible (Caspary \& O'Connor, 2003). Moreover, new communication technologies especially are disrupting traditional business models and forcing business to innovate and to reinvent themselves (Graham, Hjorth, \& Lehdonvirta, 2017). With this said, challenges related to impacts of ICT on traditional knowledge and stability/integrity of Northern communities are significant and must be addressed (Young, 2017, Young, 2019).

A number of regional, national, and international reports have carefully documented the rise of the creative economy (Bakhshi, Freeman, \& Higgs, 2012; Duisenberg, 2010; Harris, Collins, \& Cheek, 2013; Restrepo \& Marquez, 2013). As 2013 UNESCO Creative Economy Report points out, "culture is now a driver [emphasis in the original document] of economic development, led by the growth of the creative economy in general and the cultural and creative industries in particular, recognized not only for their economic value but also increasingly for their role in producing new creative ideas or technologies, and their non-monetized social benefits" (p. 9).

As a consequence, scholars and policy makers alike have paid close attention to scalable, specific strategies and policy instruments that boost both public and private investment in cultural activities and creative occupations (Florida, 2002; Hagoort, 2003; Kooyman, 2011; Oakley, 2004; Sorin \& Sessions, 2015). Furthermore, the question of educating a digital creative workforce has resulted in considerable dialogue concerning how to develop culturally specific or culturally sensitive entrepreneurship training curricula for the creative economy and to make these accessible, for broad community audiences, online (Naudin, 2017; Röschenthaler \& Schulz, 2015).

In this chapter, as a component of the section related to renewable Arctic economic opportunity, we examine the potential of developing such culturally specific or culturally guided entrepreneurship training curricula, and the access and/or barriers faced by aspiring entrepreneurs in remote Arctic communities, as they seek to utilize new communication technologies and digital tools (photography, videography, code, etc.) to generate sustainable job opportunities. Specifically, we seek to address the following questions:

1 What access do remote Arctic communities have to broadband technology and digital tools to participate in the creative economy?

2 What concerns and barriers do remote Arctic communities face in developing viable business opportunities in the global creative economy?

3 What opportunities already exist in remote Arctic communities for participation in the global creative economy? What conversations about jobs outside of the resource extraction economy and traditional subsistence are being had? 


\section{Background}

\section{Currents trends in Arctic environments and economies}

The North American Arctic is undergoing measurable, visible and significant environmental, economic, and social changes. Observable warming trends in the Arctic present significant and sustained challenges including, but not limited to ecological shifts such as observable differences in animal migratory patterns, hunting range, ice thickness, and numerous other threats to traditional practices and ways of life (Stroeve, 2017; Wang, 2017). Such developments represent a significant challenge to traditional economies, along with associated sociocultural, environmental, traditional knowledge and linguistic/communicative concerns (Emmerson \& Lahn, 2012; Giles, 2003; Romero Manrique, Corral, \& Guimarães Pereira, 2018; Stephen, 2018).

The warming/heating trends, despite the significant challenges mentioned above, may also paradoxically present some economic opportunities in the North American Arctic, through enhanced shipping and transport, mineral exploration, ecotourism, and infrastructure (Drewniak, Dalaklis, Kitada, Ölçer, \& Ballini, 2018; Tol, 2009). This is evidenced in-part by enhanced global interest in Arctic shipping routes, increased activity in Arctic-based diplomatic and negotiating activity and geopolitical interests and stakes proposed by an increased number of (thirteen as of this writing) Arctic observer nations such as China (Arctic Council,n.d.)

These trends in the North American Arctic have raised concerns related to sovereignty over Arctic waters. Canada is particularly focused upon Arctic sovereignty and definitions (by the United States and other nations) of the Northwest Passage as either internal or international waters, issues that will impact oversight of environmental conditions and resources, reduce the ability to control shipping traffic and collect duties, and influence access (Geddert, 2019; Lajeunesse \& Huebert, 2019; Lalonde, 2018; Stein, 2018). Initiatives such as China's Polar Silk Road and guidebook for Chinese ships navigating the Northwest Passage are examples of international attention to and attempts to begin using the passage at large scale (Byers \& Lodge, 2019; Koivurova, 2018; Liu, 2019). Such national sovereignty concerns directly impact economic opportunities and are linked to the sovereignty of the Indigenous populations of the Arctic.

While much of the North American Arctic economy is currently focused on commodity extraction and exports, resource-dependent communities prone to boom-and-bust cycles are looking toward digital and creative economic models as tools to diversify their economic base (Alvarez, Yumashev, \& Whiteman, 2019; Avango, Nilsson, \& Roberts, 2013; Bennett, 2016; Johnston, Dawson, \& Stewart, 2019; Nong, Countryman, \& Warziniack, 2018; Poppel, Flaegteborg, Siegstad, \& Snyder, 2015). Developments such as the Arctic Investment Protocol of the World Economic Forum and early 
adopters such as Guggenheim Partners indicate a global interest in how Arctic development proceeds (World Economic Forum, 2015).

The rise of the creative economy and its economic and social impacts have been widely documented and one tool for enhancing economic development of this type is through the creation of curricula in accelerators and incubators (Connell, 2013, Felton, 2010, Flew, 2011, Heinsius and Lehikoinen, 2013, Oakley, 2004; Sorin \& Sessions, 2015). A key goal of these programs has traditionally been to prepare entrepreneurs to start businesses in the creative and cultural sectors, and some of these programs have been specifically designed to address underserved minority populations (Leung, 2019; Salemink, Strijker, \& Bosworth, 2017; Sum \& Jessop, 2013).

As of this writing, a large number of these efforts have focused on major urban centers despite the fact that it is especially in the highly remote and underdeveloped regions of the planet where the digital/creative economy can be the most effective for economic diversification and poverty reduction (Florida 2006, Markusen and Gadwa, 2010; Duisenberg, 2010; Philip \& Williams, 2019; Restrepo \& Marquez, 2013).

\section{Digital entrepreneurship education: From North American tribal colleges to community efforts}

Tribal Colleges and other Native American Tribal groups in the United States are engaging with culturally centered digital/creative incubators designed around economic development (Dana \& Anderson, 2007; Dixon, 2019; Wuttunee, 2004). And in a most recent example, an Australian not-forprofit accelerator, Barayamal, is now offering a variety of entrepreneurship education programs for tech startups, specific sensitivity and inclusion of Kamilaroi language elements ("Barayamal - Indigenous Entrepreneurship Australia," 2019.)

In the Pueblo Nation, an accelerator was conducted entirely in the Zuni language, enabling youth to participate in the Indigenous Comic-Com focused on Native Superheroes and creating new series focused on Native Realities: Superheroes of Past, Present, and Future (Murphy, 2018; Simón, 2016).

Shoshone-Bannock Tribal Member and Indigenous Journalist Mark Trahant has written extensively on the importance of digital content creation by Indigenous Peoples. As co-author and presenter with Pasch, Bjerklie, \& Trahant (2016) at the ArcticNet Annual Scientific Meeting, he wrote:

So what can we in the Academy do about this? How do we make certain that the opportunity for a digital future is as real for an Indigenous Arctic as it for other global citizens? As we develop digital media we must not allow ourselves to repeat mistakes from the past, and especially the missing voices from Indigenous communities. I am fond of the work of the 1947 Hutchins Commission, formally the Commission on Freedom of the Press (Hutchins, 1947). That Commission said underrepresented 
"constituent groups" are too easily misrepresented in any democracy. "We cannot assume (that) the mere increase in quantity and variety of mass communications will increase mutual understanding,' Hutchins wrote. "It may give wider currency to reports which intensify prejudice and hatred" (Hutchins, 1947, p. 35). So, again, what can we in the Academy do about this? What can we do to make sure that in the Arctic indigenous voices are developing stories, content in digital-speak, and more important, being heard?

One of the challenges for Indigenous communities, including the Arctic region, is that we need better data about Internet or cell phone service. If you look at Facebook, Instagram, Snapchat, Twitter, and other social media, it's clear that Native young people use social media in similar ways to other young people. It's also important to remember that the Indigenous population skews younger than the general population, and in many communities the under-18 age group constitutes the largest population segment of typically fast-growing communities (Census Canada, 2017).

Indigenous communities already have a data gap. Many of our statistics, ranging from unemployment to health metrics, are unreliable and out of date. We need better, faster data collection in Indigenous communities, in North America and globally (Kukutai \& Taylor, 2016). The National Congress of American Indians says when it comes to data Native Americans are too often the "asterisk nation" because the information we see is scant and presented as a footnote ("Data Disaggregation NCAI," 2019). http:// www.ncai.org/policy-research-center/research-data/data

A second opportunity here is the lifting of geography as a barrier. In the digital world, location does not matter. A business can operate successfully anywhere there's a good connection to the Internet. The retail site Etsy is a good example. According to Mary Meeker's research (2018), 35\% of Etsy sellers started a business without much capital (compared to $21 \%$ of all small business owners). It's the perfect space for authentic Indian art.

The important thing is that we are at the beginning of the digital transformation. American Indians and Alaska Natives have a long history of adapting to new technology. This is just a new and exciting chapter. What's interesting to us is that we need more of this across the Arctic. The talent is already there. We just need to open up more opportunities for its use and an exposure to a broader audience.

Our incubator and accelerator approach establishes a visible physical presence for sustainable economic development through the creation of Indigenous-owned businesses, assisting with training including but not limited to digital content production, expanding conceptual and practical possibilities for data sharing and collaboration in Arctic communities, and broader impacts (Mark Trahant, in Pasch, Bjerklie, \& Trahant, 2016).

One major barrier to successful entrepreneurship education and training in the Arctic relates to historical and present-day postcolonial and neo-colonial 
ramifications. Some previous efforts to adapt entrepreneurial education to the specific needs of Indigenous communities have inadequately addressed significant aspects of cultural imperialism/hegemony (Pinto \& Blue, 2016). The concept of the institutionalized othering of Indigenous peoples in their own lands, and aspects related to glorifying "saviors" of a highly idealized/ romanticized Arctic have been explored in the literature (Huggan \& Jensen, 2016; Jensen, 2015; Pasch, 2015). Some existing Western entrepreneurship approaches have primarily utilized traditional models of capitalistic entrepreneurship training and merely "translate" or localize them into a different cultural and linguistic context, without questioning the fundamental concept of entrepreneurship itself - or its fit for Indigenous communities. Programs of this type may not be aligned with local community values and the various types of remote-community entrepreneurship and ownership (from sole proprietorship to tribally owned cooperatives) that are possible, and which of these might fit the community and its individual's best.

This chapter argues that attempts to "train" Arctic residents in curricula created elsewhere may impart little result or benefit, or may arguably even be highly detrimental to remote communities in the Arctic and other regions - unless the curriculum is the result of a collaborative effort including culturally specific ways to integrate Indigenous knowledge directly into entrepreneurship training.

With expanding digital connectivity in the Arctic, the question of how future economic development in the North might proceed has become a more pressing question, as seen by increasing research into Arctic entrepreneurship, youth engagement, small business development through resilience and other programs in the circumpolar Arctic. A number of new programs have emerged across the Canadian and Alaskan North related to these goals.

Inspire Nunavut is one example of current Canadian-funded teams working on social entrepreneurship training in the Canadian North, focused on incorporating Indigenous values into curricular design and partnering with local participants and leaders. Merging the driving principles of traditional business with the mechanics of social entrepreneurship, while also integrating Inuit culture and values, "Inspire Nunavut provides youth in Nunavut with an opportunity to create new solutions in their communities via entrepreneurship" ("Inspire Nunavut,"n.d.). Through integrating Inuit traditional knowledge principles with entrepreneurship training this program has partnered with the Government of Nunavut and Employment and Social Development Canada, and has already shown success in the creation of new businesses in remote communities in Nunavut ("Inspire Nunavut,"n.d. ; Cornik, 2016)

EntrepreNORTH is a program based out of Yellowknife, Northwest Territories with its mission focused toward empowering Indigenous and community-based entrepreneurs to build sustainable businesses and livelihoods across Northern Canada. EntrepreNORTH provides a Northern Entrepreneur Support Program in addition to powerful thematic approaches 
(for example, an On-the-Land Tourism Experiences and Services program) that has resulted in numerous Indigenous-owned companies. As indicated in the Impact Stories of the site, "Across Northern Canada, Indigenous entrepreneurs are catalysts of prosperity and drivers of social change within their communities. Their success has a far-reaching ripple effect that leads to greater Northern self-determination and sustainability" ("EntrepreNorth," n.d.).

TakingItGlobal has developed the ConnectedNorth program offering enhanced educational experiences for remote Indigenous communities via partnerships with Cisco and other organisations. ConnectedNorth's principles build upon empowerment through Indigenous role models and principles incorporating a diversity of voices and making strong use of technologies to share educational experiences at a distance.

In Alaska, the Tanana Chiefs Conference (TCC), and its corporation, Doyon Ltd. is also focused on economic development. This tribal consortium consists of 6 sub-regions and 42 member tribes of the (primarily Athabaskan) Alaskan Interior. Their territory covers an area of 235,000 square miles, an area equal to about $37 \%$ of the entire state, and just slightly smaller than the state of Texas.

In addition to leading initiatives in areas such as health, housing and environment, wellness, sustainability and energy; rural economic small-business development has become an increasing priority for the Conference. The TCC is working toward multiple economic initiatives including ecotourism as well as investing in small businesses viewed as viable and based on/ aligned with community plans ("Tanana Chiefs Conference," 2019). The Alaskan fieldworks informing this chapter took place in collaboration with the TCC and most particularly in the communities of Hughes and Huslia in the Yukon Tanana and Yukon Koyukuk subregions (see Figure 2.1).

While the Tanana Chiefs Conference represents a large part of the Alaskan interior and focuses on economic development and job training programming, currently they have not yet developed an incubator or accelerator program. The creation of these opportunities, especially as informed by currently existing initiatives in Canada and other parts of the Arctic we believe, is fortuitous given increasing connectivity among and with remote Alaskan communities. At a recent Navigating the North Summit in August 2019, the theme focused on "Telecommunications and Technology to Arctic Economic Development and Public-Private Partnerships: Corporate, Government and Industry Leaders Focusing on the Rising Potential of Alaska" ("Navigating the North - Innovation Summit 2019," n.d.). One panel in particular discussed future investment opportunities in Native communities, and the necessity of broadband expansion. This connectivity could enable not only in-person incubator and accelerator programs, but also allow for online and hybrid programming to be supported by broadband communication technology such as conferencing, webinars, and other forms of online learning.

Traditional urban accelerator programs, focused on the tech industry, who invest in the companies they help launch, also already exist in Alaska. 


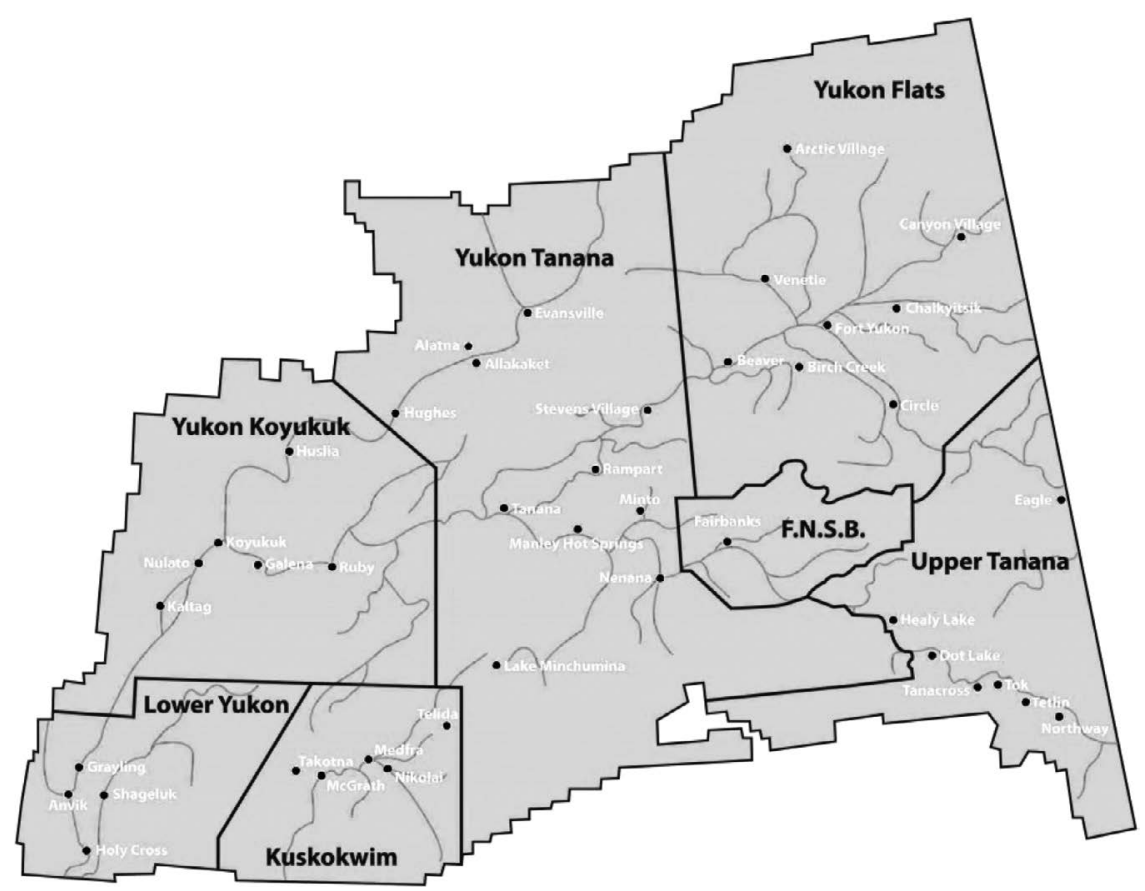

Figure 2.1 Territory and subregions of the Tanana Chiefs Conference.

Take for example Launch Alaska, an Anchorage based tech start-up accelerator with a variety of companies in their portfolio ("Launch Alaska," 2019). Launch Alaska provides the typical model for start-up companies: they guide promising new companies through an educational program-acceleration - and then invest in a selection of them, receiving part of the company's equity in return for the continued technical assistance and networking. In contrast to this urban program in Alaska's largest city, few other accelerator or comprehensive start-up entrepreneurship education programs exist across the state, especially in more remote communities.

In summary, there are currently a variety of efforts on the way to integrate Canadian First Nation knowledge and curriculum with existing entrepreneurship training approaches. In Alaska, that process is very much in its infancy, with a more traditional urban technology accelerator in place. Yet, all of these programs have successfully helped launch a number of (Indigenous) businesses that either serve their communities with modern services or sell Indigenous goods and services to a larger market. One area where both the Canadian and Alaskan Arctic continue to struggle in remote communities, relates to the challenge of digital access and bandwidth. 


\section{The current State of Arctic digital access: Community informatics, digital media, and bandwidth}

North American Arctic Bandwidth has the potential for enhancements in the near future, which (if successful) may significantly impact Arctic economic development in remote regions. In 2017, the Quintillion Corporation succeeded in finalizing subsea connections linking the Alaskan community of Nome with Prudhoe Bay (and communities between), after which point terrestrial cable connects with Anchorage and Seattle. Phase Two of the project proposes submarine fiber optic cable between Alaska and Tokyo.

For Alaska and the Canadian Arctic, the proposed eastern extension of the network in Phase Three extends through the Northwest Passage in Canada and from there onwards to the United Kingdom. In a September 2019 telephone discussion with Zach Naramore of Quintillion it was described that the exact route East through the Northwest passage has not yet been finalized. Ultimately, the route will depend on building a business case that would allow us to successfully build the infrastructure, and then have customers benefit from ... being in that location (based on) the geography.

Madeleine Redfern, the Mayor of Iqaluit Nunavut, indicated to the Special Senate Committee on the Arctic that Canada had missed out on connecting Baffin Island to fiber-optic lines from Nuuk, Greenland to Newfoundland. Redfern, 2018) stated that "you effectively cannot put a branching unit in after it has been built. It is as expensive as a new build." She called for the construction of a fiber link from "Iqaluit to Nuuk at a cost of approximately $\$ 80$ million; a cost that would have been reduced by half had a branching unit been installed in the original design phase" ("Senate of Canada- Northern Lights: A Wake-Up Call for the Future of Canada," n.d.).

Given that client needs will impact the final route selection of the Quintillion Network proposed in 2021/2022 through the Northwest Passage, it may potentially be advantageous for Internet connectivity in Nunavut and Nunavik (and other Canadian Arctic regions) if successful negotiation between policymakers in the Canadian North could link remote Canadian Arctic communities during the third phase of this major North American Arctic infrastructure development.

Beyond Alaska, other Arctic regions including Cinia (Finland) and MegaFon (Russia) have created memoranda of understanding related to sub-sea data cable across the Arctic Sea. These connections also link Russia and China with the network, which raises a number of potential security concerns for the North American Arctic.

As one example of Arctic data security challenges, Huawei Corporation (China) indicated that it would partner with Ice Wireless and Iristel to help them connect (by 2025) rural communities in the Arctic as well as remote areas of north-eastern Quebec and Newfoundland and Labrador. Huawei added that some 25 communities in the largely Inuit areas of the Nunavut 


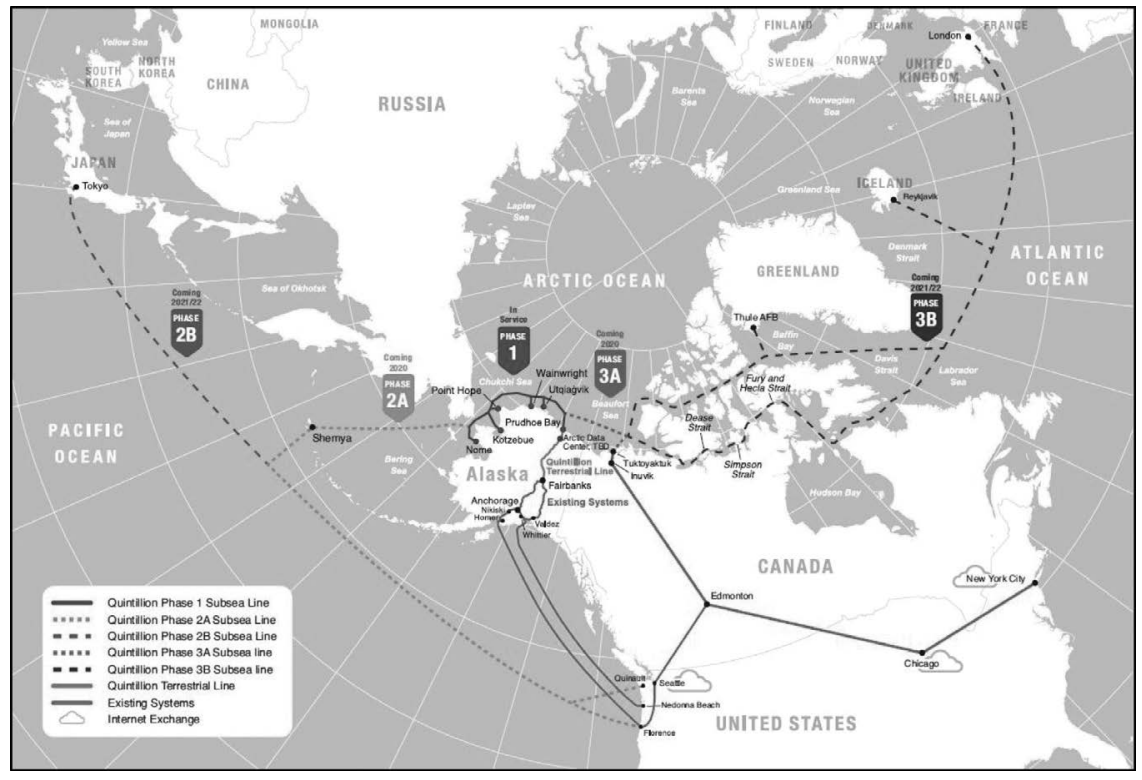

Figure 2.2 Quintillion Arctic broadband development strategy.

Source: https://www.qexpressnet.com/system/\#FAQ

territory would also benefit from the deployment. One concern related to Huawai's presence as a communication leader in the Canadian Arctic mentioned that this "does create a vulnerability in the event of an escalated Canada-China dispute, where Huawei could potentially be ordered to shut down those services, thus cutting Canadian Arctic communities off the Internet" (Byers \& Lodge, 2019; Levinson-King, 2019).

Beyond the risk of services being shut down in the Arctic, questions of security in terms of United States/Chinese data sovereignty challenges have been frequent in the media as of this writing, and data for the Canadian North managed by Huawei could have further contraindications on United States/Alaskan collaboration and data management.

While some specific Arctic centers have achieved significantly fast(er) data speeds than previously due to $4 \mathrm{G}$ LTE connectivity, there remain numerous Arctic communities where data is either completely lacking, or provided at a significant premium resulting in higher costs and major limitations in what is possible for North American Arctic entrepreneurship and small business development. Eric Anoee, an Inuit member of the board of the Nunavut Broadband Development Corporation expressed his view with the authors when asked if Internet speeds in the Arctic are an issue: "Yes, it is definitely an issue but we make do with it ... ideally it should be on par with the rest of Canada. They (Internet speeds) should be seen as a Basic Human Right to have the same level of service with other Canadians." 


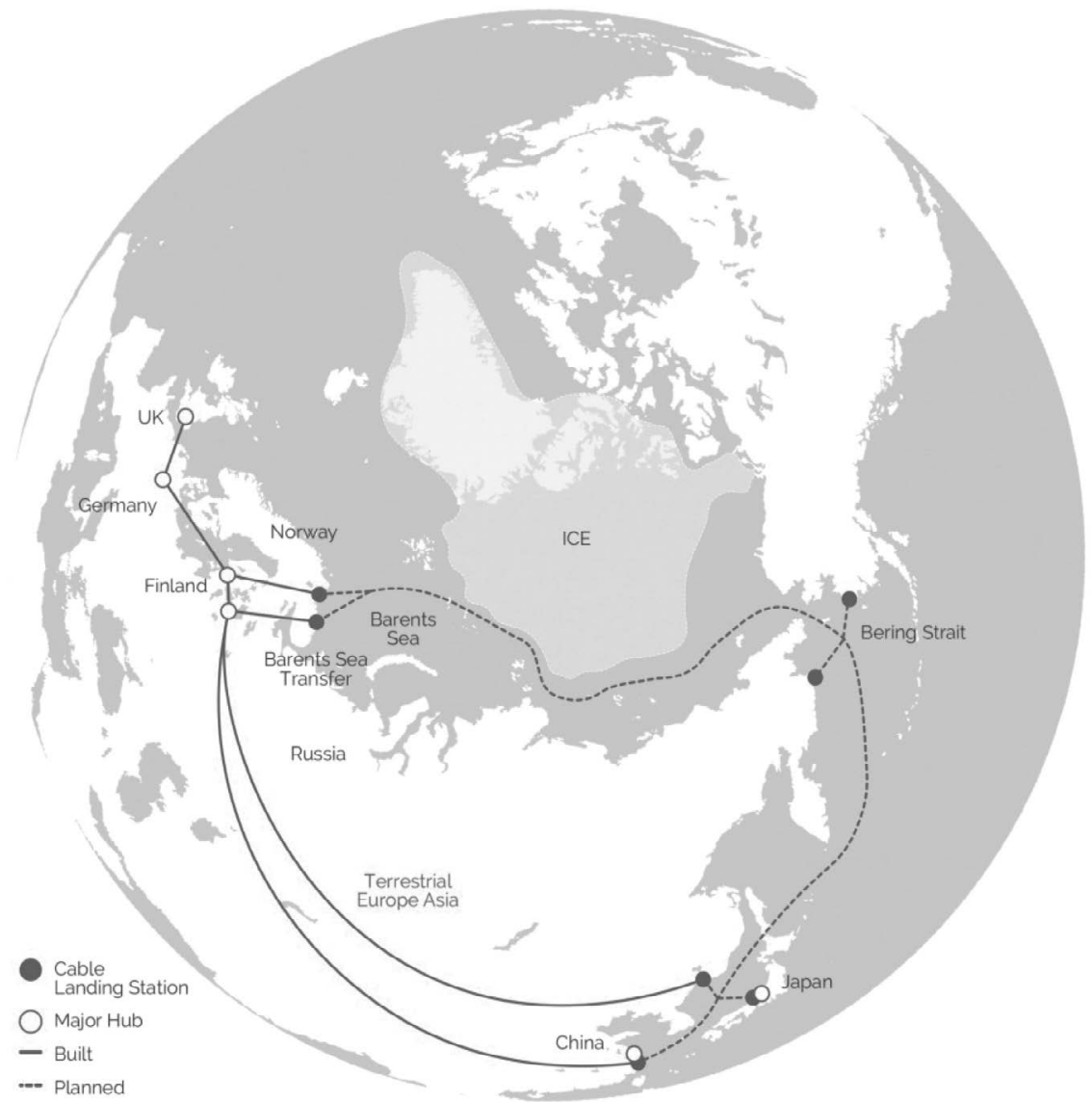

Figure 2.3 Cinia/MegaFon proposed Arctic sea digital communication strategy (Knaapila, 2019).

Some data services to Nunavut are currently delivered via Telesat satellites running through gateways in each of the 25 Nunavut communities. Despite the 4G upgrades, wireless internet is a far cry from broadband connectivity enjoyed by most of southern Canada. This may change due to significant investment from the Government of Canada into R\&D for Telesat's broadband satellite constellation that may enable connectivity for the most remote Arctic communities.

Minister of Innovation, Science and Economic Development Navdeep Bains said July 24 that the Canadian government views Telesat's future low Earth orbit broadband constellation as the only means to connect the country's most remote citizens. "This is going to provide us with privileged access to this constellation, which will enable us to get 
high-speed internet connectivity in rural and remote parts of Canada, and consistent with the commitment that we made in the budget where every single Canadian will have access to high-speed internet access by 2030," Bains said in a call with reporters"

(Henry, 2019).

In the June 2019 Canadian Special Senate Committee on the Arctic Final Report, it was stated that "The Canadian Arctic lags far behind the rest of Canada and other circumpolar countries in digital connectivity. Reliable and affordable broadband telecommunications services can improve the delivery of public services, help to preserve culture and language and enable economic diversification by connecting remote communities to each other and the rest of the world. Broadband telecommunications access in the Arctic is poor and, where available, expensive" (p. 45).

These findings were confirmed in conversations and community workshops during the summer of 2019 in the Kivalliq region of Nunavut and in the Alaskan interior. Some commentary related to technology included expressions of frustration such as: "We get really limited on what we can do using the web. And it's unaffordable to use the internet, especially for the low-income parts of our population. Because obviously will you choose internet over food? You have to have the food" (Arviat, Nunavut).

The Honourable Paul Aarulaaq Quassa, Premier of Nunavut indicated that: "Connecting Nunavut with the rest of Canada through roads, fiber optics, telecommunication lines and electricity corridors would positively impact our territory in many ways: reducing our reliance on fossil fuels and impact on the environment; reducing the cost of food, goods and services through increased shipping methods; and increasing our participation in the digital economy and reducing the digital divide" (Quassa, 2018).

In the publication High-Speed Access for All: Canada's Connectivity Strategy produced by Innovation, Science and Economic Development Canada (ISED) in 2019, the Minister of Rural Economic Development describes that in 2019 "we made a bold commitment to connect all Canadians to reliable high-speed Internet" (p. 2). The document continues that "Canada faced a national connectivity gap" with rural communities facing "the daily challenge of slower, less reliable Internet access than those in urban centres" (Innovation, Science and Economic Development Canada, 2019, p. 4). The report additionally confirms that "limited Internet has proven to be a real and significant challenge for Indigenous communities" with focus on affordability and connectivity made available within communities rather than requiring relocation (Innovation, Science and Economic Development Canada, 2019, p. 13). "The Rural and Northern Stream of the Investing in Canada Infrastructure Program provides up to CAN $\$ 2$ billion to support various infrastructure projects that improve the quality of life in rural and northern communities" (Innovation, Science and Economic Development Canada, 2019, p.18). 
Infrastructure of this type, while transformative for Arctic economies in the Canadian North, at present are "still very fragile: a single event can cause a mass outage where people can't send or receive emails, people can't get money out of the bank machine, people can't buy gasoline or groceries at the store," stated Madeleine Redfern (Levinson-King, 2019).

Beyond land-based Internet possibilities a number of other space-based Internet options may potentially render undersea and terrestrial cable redundant. In particular for the Arctic, even if undersea connections are made, laying fiber on the tundra brings with it a host of other challenges related to permafrost, extreme weather conditions and the challenges of access to such remote regions.

OneWeb is a company proposing future space-based blanket coverage for the Arctic, in addition to Amazon's Project Kuiper, SpaceX's Starlink, Facebook's Athena and Google's Loon (among other companies). While Iridium phones are presently commonplace in the Arctic, until recent times connection speeds for data at $2.4 \mathrm{kbps}$ have been largely insufficient to enable large-scale remote-region digital communication and data transfer. The new Iridium NEXT satellite constellation array has the potential to blanket the North with high-speed communication technology. While in coming years there may indeed be a host of new devices connecting with new networks enabling enhanced digital communication in the Arctic, at present the reality is that when away from major communities data can be extremely sparse indeed.

\section{Community informatics: Beyond data speed and focusing on community values}

The importance of training in information technology, as well as job creation and participation in markets for digital products is widely recognized as essential for economic growth in modern economies. Key to the implementation of creative economic initiatives in rural and underserved regions is local access to and familiarity with information technology and digital media (Robert and Townsend, 2016). The importance of training in information technology, as well as job creation and participation in markets for digital creative products is widely recognized as essential for economic growth in modern economies (Comunian, Gilmore, \& Jacobi, 2015). And yet a digital divide still remains a limiting factor in many regions, including much of the circumpolar Arctic.

Even when high speed data is available (for example, the 4G LTE service available in Arviat via the qiniq system), the high cost of data coupled with immediate data caps when limits are exceeded means that monthly data limits can be reached extraordinarily quickly, effectively limiting the ability of Nunavummiut to upload films, transmit datasets, conduct live video meetings, and conversations, and participate in training sessions, as only some examples. 
Regardless of when broadband arrives in Nunavut, it is not merely speed of connectivity that can create value for a community. This chapter argues that economic and social value for a community is not solely based on the rapidity of digital connectivity. A number of researchers have proposed that it is not sufficient to merely overcome this digital divide by providing faster access, but rather by focusing on the real needs of users. "A preoccupation with the digital divide as a problem of technical connectedness more often than not serves the commercial interests of Internet service providers (ISPs), without necessarily empowering or addressing the critical needs of those one is striving to connect" (Clement, Gurstein, Longford, Moll, \& Shade, 2012, p. 16).

Some research like Landzelius (2006) has shown that increased passive consumption of digital commercial content (especially by youth) may be strongly at odds with cultural values and traditional knowledge. Community Informatics Theory argues that communities collaboratively accomplishing meaningful self-determined goals utilizing technology/data provide a far more valid measure than data speeds alone, of enhancing economic opportunity while overcoming digital disparity (Kuersten, 2018; McMahon, Gurstein, Beaton, O’Donnell, \& Whiteduck, 2014). Jason C. Young (2019) focuses on the impact of information and communication technologies on communities and especially on Inuit qaujimajatuqangit and knowledge transmission. In this piece, the author (2019) discusses how digital technology is negatively impacting the amount of time spent on the land and outdoors, degrading interactions between children and elders, and creating concerns not only by serving as a distracting element while on the land, but also replacing actual skill (such as navigation and situational awareness) with digital tools functioning as ersatz replacement for traditionally learned abilities. Both in terms of social interactions and learning, technology carries with it numerous aspects of the post-colonial and real dangers in terms of cultural appropriation, and the balance that the author discusses between "good" and "bad" uses of ICT are highly applicable to digital entrepreneurial curricular economic development as it is being developed in the North American Arctic. Community Informatics Theory and the thoughtful, valuedriven creation of economic initiatives may assist in addressing some of the challenges researched in Young's research.

In summary, there is tremendous potential to expand the fast-growing global creative economy to Arctic regions. A key advantage of this sector is the fact that many products and services developed under this rubric are digital in nature, such as (but not limited to) audio and video production, podcasting, still photography, augmented and virtual reality games and applications, coding, telepresence and numerous others. With broadband access, the remoteness of the Arctic can be overcome, and the resource extraction economy could be supplemented and even replaced in the long run by a digital creative economy that reduces the typically high transportation costs and creates location-independent jobs. Once proper, equal, 
reliable and affordable broadband options are in place, value-based entrepreneurship programs (incubators/accelerators) can offer opportunities for remote populations to participate in opportunities the creative digital economy has to offer. There are challenges related to such efforts, which are described in detail in the following chapter.

While this research argues that a culturally aligned and communityfocused digital creative business incubator can assist in the development of new companies and jobs in remote regions, the implementation of any entrepreneurship incubator/accelerator requires careful study of the values that communities themselves see in such a program, especially listening in terms of self-determining strengths, challenges and opportunities. Toward this goal of listening we conducted fieldwork in May and June 2019, as described in the following sections.

\section{Methodology and research approach}

The fieldwork informing this chapter was funded by the National Science Foundation grant: Developing and Testing an Incubator for Digital Entrepreneurship in Remote Communities. The goals of the project include conducting listening sessions toward informing the co-creation of a culturally centered curriculum on digital entrepreneurship for the purpose of enhancing economic and social opportunities in remote North American Arctic regions.

Conceptually, the project is based on the belief that any curricular design focused on sustainable digital economic development in the Arctic will be ultimately unsuccessful without fully incorporating (from the earliest phases of development) traditional knowledge, respect of each Arctic community's communicative and linguistic preferences, and the foundational incorporation of traditions and community-based consensus of value and needs. We argue that digital technologies and communication infrastructure and curriculum intelligently leveraged toward creative and culturally situated small business opportunities can assist in diversifying the economic development of the Arctic's remote and resource-dependent communities.

To assess the likelihood of successfully creating a curriculum for digital entrepreneurship training in the Arctic, we first examined existing access to the telecommunication infrastructure in the North American Arctic. This was done through an extensive literature review as well as interviews with telecommunications providers and specialists in our host communities. Second, we conducted interviews with community members, workshop participants and key stakeholders in order to assess the personal, cultural, economic, and social barriers to both telecommunication access as well as business development, including entrepreneurship. Third, we examined the many existing opportunities for telecommunication access as well as business development, and we discuss our findings below.

Our initiative additionally proposed to connect regions of Arctic Canada with regions/communities in Alaska, thus enabling the cross-pollination of 
ideas and sharing of digital infrastructure and communicative networks/ databases that may assist in elevating the scale and scope of small businesses to ultimately become Indigenous-owned Arctic digital enterprises, potentially with linkages connecting Canada and the United States.

In May and June 2019, we traveled to Nunavut and to the Alaskan Interior for initial discussion and workshops with Inuit and Alaska Native tribal members. We conducted research in the form of workshops, interviews, survey collection (in person and online), and in-person focus groups in the Hamlet of Arviat, Nunavut, Canada, and with the Tanana Chiefs Conference in Alaska, specifically in the Alaskan interior communities of Hughes, and Huslia as well as Fairbanks. We interviewed local tribal leaders, small business owners, and residents of the areas and conducted participatory workshops with members of the respective communities (ranging from one to five days) to learn more regarding shared traditions, values, small business opportunities, and economic challenges related to living and working in the North American Arctic. We additionally brainstormed regarding possible economic collaborations between Alaska and Nunavut, as well as about similarities and differences between Alaskan and Nunavummiut perceptions of challenges and possibilities for renewably growing the creative economy in both regions. While in Alaska we traveled together with an Inuk colleague working toward facilitating in-depth discussions between Inuit and Alaska Native peoples in order to further enhance understandings of collaborative economic potential between Indigenous peoples of the United States and Canadian Arctic.

This initiative takes the perspective that any work with Arctic Indigenous communities on economic development, including that made possible through digital media and technology must respect and work with traditional value systems, and should result in a co-designed program, strategy or curriculum that ends up being owned by and led by Indigenous people (Castleden, Morgan, \& Lamb, 2012; Ermine, Sinclair, \& Jeffery, 2004; Louis, 2007; Nicholls, 2009; Weber-Pillwax, 2004). Thus, our workshops with the community sought to establish a conversation about the value system that guides community-based economic thinking and identifies perceived strengths and challenges; and based on that, develops ideas for the most needed businesses and the digital components that help promote them. The Technology of Participation (ToP) approach assisted in organizing the process of inquiry designed around a highly inclusive, listening focused approach (Nelson, 2017).

According to this phenomenological approach to inquiry, we began with a focused conversation topic, and asked participants to identify, without prompting or interruption, various characteristics of their communities: strengths and challenges, and the traditional as well as modern values they perceive as guiding them. Furthermore, participants discussed digital tools and aspects of data access that were viewed as economic opportunities for the community (and region), while also calling out aspects of Arctic digital infrastructure that were viewed as significant barriers to overall communication and successful small business development. 
As facilitators, we stepped back, observed and did not interrupt or guide this process. This brainstorming was followed by a group consensus workshop, the second part of a typical ToP session. Here, participants begin to discuss, sort, categorize and prioritize various ideas, and come to a collective group consensus on their key values, strengths and challenges. Participatory strategic and action planning - the next steps of ToP-followed, and community participants identified which business ideas and future economic development would address the strengths and challenges, while being true to community values. Technology of Participation techniques have been widely used in a number of contexts and communities (including Indigenous communities) as small and large group interaction methods to facilitate difficult conversations about major community change efforts and challenges, and to develop action plans for the opportunities that exist (Bryson \& Anderson, 2000; Nelson, 2017; Spencer, 1989).

The means by which ToP is framed is critical (Lee, McQuarrie, \& Walker, 2015). "Technologies of participation refers to arrangements of practices, metrics, discourses, and actors that perform community self-determination in ways that are designed to realize specific goals ... deliberation can be sold as a commodity or it can help create group solidarity and identity ... it can enable democratisation or elite rule. It derives its significance from how it is situated" (Lee, McQuarrie, \& Walker, 2015, p. 83). For this reason, the synergy of Indigenous-centered research methodologies and community informatics theory with ToP was critically important for developing a conceptual framework designed toward enhancing benefits to communities while reducing negative influences of technology, economic development and digital in-roads.

As part of the workshops, many discussions took place outside hamlets/ villages and out on the land. The conceptual framework guiding these discussions was in part driven by the perspective that even being indoors inside fixed-style houses was a colonial construct, and that being outside in traditional ways could create new opportunities for freedom of expression and heightened communication. For this reason on day 3 of the workshop in Arviat the group traveled overland via snowmobile and discussed at length in an environment much more conducive to communication. Many conversations took place in Inuktitut. In Alaska, similarly the group left the tribal meeting halls to meet by the riverbanks and discuss, in addition to boat travel upriver and forest walks/ATV travel.

\section{Developing an Arctic digital creative economy of the future: From values to challenges and strengths}

\section{Values}

During our fieldwork in both Arviat, NU and Hughes, AK, we began our community workshop with a lengthy discussion of values. We asked the community members to identify the values that guide their work, and their life in 


\begin{tabular}{|c|c|c|c|}
\hline \multicolumn{4}{|l|}{ Arviat, NU Values } \\
\hline Love & Family & Unity & Listening \\
\hline Teaching & Respect (elders) & Loyalty & Mutual Help/Cooperation \\
\hline Respect & Love & Appreciation & Wisdom \\
\hline Serenity & $\begin{array}{l}\text { Preparing for the } \\
\text { Future }\end{array}$ & Trust & Commitment \\
\hline Honesty & Patience & $\begin{array}{l}\text { Cultural } \\
\text { Awareness/Steadfastn } \\
\text { ess }\end{array}$ & Integrity \\
\hline \multicolumn{4}{|l|}{ Hughes, AK Values } \\
\hline $\begin{array}{l}\text { Knowledge of the } \\
\text { land }\end{array}$ & Unity & $\begin{array}{l}\text { Knowledge of Culture } \\
\text { and Tradition }\end{array}$ & Willingness to learn \\
\hline Subsistence & Community Unity & Hospitality & Caring for each other \\
\hline $\begin{array}{l}\text { Seasonal } \\
\text { Changes }\end{array}$ & Cultural unity & $\begin{array}{l}\text { Cohesion: Everyone } \\
\text { pulls together in time } \\
\text { of need }\end{array}$ & $\begin{array}{l}\text { Love and Care for } \\
\text { Children in Community }\end{array}$ \\
\hline $\begin{array}{l}\text { Working together } \\
\text { to keep drugs out } \\
\text { of community }\end{array}$ & Progressive attitude & Respect for Elders & Friendliness \\
\hline
\end{tabular}

Figure 2.4 Graphical summary of the most frequently used terms in discussions in Arviat and Nunavut.

the community. All participants were asked to identify key values that guide their work and their actions in the community, and to place these on the large interactive wall ("sticky wall") used in Technology of participation sessions.

Each participant then ranked their top two (2) priorities in each category. The priorities were then ranked in descending order with the most frequently ranked priority at the top of the column. A graphic summary of the most frequently used terms during discussions in Arviat and Nunavut follows in Figure 2.4.

Some elements that rapidly emerged in discussions included

a The necessity of co-creation in all business endeavors. This means that in small communities, no business should operate without prior consultation with the community, and with a clear mission to serve the community. In other words, there must be value alignment between individual business owners and the community.

$\mathrm{b}$ The focus on incorporating strong Indigenous socio-linguistic, traditional, elder-guided curricular aspects into all enterprises. New business development should strengthen the cultural fabric of the community, not weaken or dilute it.

c The development of trust and resilience. The communities we worked with expressed a strong need for emphasizing historical continuity and 
the value of tradition. It was expressed repeatedly that elders working with youth would be a critical piece of identifying new business opportunities, since the elders highlighted the need for continuing traditions, whereas youth was interested more in modern technology and communication. Negotiating that divide, and identifying ways to bring the elders and youth together in business and in the community is critical to build sustainable businesses that are embraced by the entire community.

d The importance of having community-led data sovereignty mechanisms strongly in place. Shared knowledge and clear acknowledgement of historical past wrongs (and current pitfalls), along with the importance of leadership held by both Indigenous and non-Indigenous researchers working in a joint partnership were described. Individual and social/societal values were described as being a critical part of any economic effort.

There was a great deal of discussion related to Inuit traditional knowledge or Inuit Qaujimajatuqangit (Inuit IQ) and many of the concepts discussed during the workshop were drawn from these values and described in Inuktitut. The anonymized results of these conversations on community values were shared with Alaskan communities in order to compare and contrast values informing economic development between Nunavut/Alaska. Similar discussions were held in Hughes, Alaska where it became rapidly apparent that there are strongly shared guiding values across the North American Arctic in terms of economic and business development.

In summary, our discussions included a strong sense that any small business development should emerge first and foremost from community values, which they should be value-based and should not lose sense of their values, no matter how successful they became. In Arviat, for example, we were told about Hinaani, a local textile design/fashion company that firmly operates in the modern world (by selling apparel across North America) but that also based all of their work and designs on Inuit art, culture, and stories.

One of the first key insights we gained from our work with our host communities was that this discussion of values as part of a business and entrepreneurship development workshop was highly unusual. We were repeatedly told that while there are other job training and entrepreneurship workshops offered in both communities, we were the first in their experience to start with an in-depth conversation about values, and how values should guide business. Following a discussion of values, we then guided our workshops through an exploration of perceived strengths, utilizing the same methodology as described above.

\section{Strengths}

It became very evident throughout the weeks spent together in Nunavut and Alaska that culture and tradition were deeply important for the group, and regarded as their greatest strength. Respecting Elders and keeping 
Indigenous languages vibrant and respected were topics frequently mentioned. A mutually shared sense of volunteerism, providing community help and support to others, and continuing the critically important traditions of hunting, being on the land, and keeping the environment healthy were all mentioned as foundational priorities.

A number of individuals mentioned that so many aspects of their communities were so beautiful and attractive. "Similar to fall colors down south, up here we have very small changes in colors, in the moss and lichen, but so beautiful. The tea is so delicious. The colors on the (Hudson) bay. The Northern Lights have a deep meaning for our ancestors and for us." Discussions of sustainable, Indigenous-guided ecotourism opportunities emerged from these conversations, with a focus on what specific communityrelated events could be of economic potential, without overtly disrupting the community or causing negative impacts to the communities.

In terms of education, business and entrepreneurship, a focus on practical training for needed industries was another strong focus area. The importance of more Indigenous medical staff and members of the police force were included, as were numerous aspects of traditional skills and talents already present in the communities that could become the base for renewable/sustainable small businesses. A traditional seamstress commented in Nunavut that:

"Now we have access to everything (patterns) on computer/via the internet. We can design our own clothes and trade patterns. With amouti (traditional Inuit parka for carrying a baby) for example, we combine traditional patterns with new designs. Our designs can help people around the world. Amouti bonds the mother and child more. For the first 3-4 months some people never even see the baby as they are nestled in the Amouti. Feeding is so much easier. Skin to skin, the mother knows what the child needs so much better. The child can "go" by simply "going" on the ground while moving and traveling. There is no waste."

Numerous ideas and concepts were raised in terms of new industries and opportunities that the digital economy could make available across Nunavut and Alaska, and these are discussed in the opportunities section below.

\section{Remoteness challenges}

In order to assess what kind of entrepreneurship training the community would co-develop with us in the future, it was incumbent to address the many challenges - historical and contemporary - that remote Indigenous communities are facing. 


\begin{tabular}{|c|c|c|c|}
\hline \multicolumn{4}{|l|}{ Hughes, AK Strengths } \\
\hline Recreational Activities & Subsistence & Local Services & Environment and Nature \\
\hline ATV riding/transportation & Gardening & Community Hall & Trees/Forest \\
\hline 4-Wheeling & Hunting & Clinic & Animals \\
\hline Dog sledding & Berry Picking & Post Office & River (access) \\
\hline $\begin{array}{l}\text { Seasonal Recreational } \\
\text { Events: Community events } \\
\text { such as summer solstice } \\
\text { activity and dog sled races }\end{array}$ & Fishing & Washeteria/Laundry & Hills \\
\hline Walking & Animal Skins & Water and Sewer & Natural Beauty \\
\hline \multirow[t]{5}{*}{ Boating } & Bonding time & Strong local government/city office & Remoteness \\
\hline & Jam/Syrup & Excellent Tribal School & \\
\hline & Canning meat & Bifelt Store & \\
\hline & $\begin{array}{l}\text { Trapping (fur } \\
\text { for clothing) }\end{array}$ & Easy access to community services & \\
\hline & & $\begin{array}{l}\text { Daily flights to other } \\
\text { communities/Fairbanks }\end{array}$ & \\
\hline
\end{tabular}

\begin{tabular}{|c|c|c|c|c|}
\hline \multicolumn{5}{|l|}{ Arviat, NU Strengths } \\
\hline Practical Education & \begin{tabular}{|l|} 
Talents and \\
Skills
\end{tabular} & \begin{tabular}{|l|} 
Culture \\
Tradition
\end{tabular} & \begin{tabular}{|l|} 
Wildlife and \\
Environment
\end{tabular} & Volunteerism \\
\hline $\begin{array}{|lr|}\text { Graduation } & \text { Expansion } \\
\text { (growing } & \text { school } \\
\text { population) } & \\
\end{array}$ & $\begin{array}{l}\text { Homemade } \\
\text { Clothing, arts } \\
\text { and crafts }\end{array}$ & Respecting Elders & \begin{tabular}{|l|} 
Rich wildlife, \\
community, \\
land and \\
animals
\end{tabular} & Search and Rescue, life saving \\
\hline \begin{tabular}{|ll} 
Heavy & Equipment \\
Operators &
\end{tabular} & $\begin{array}{l}\text { Traditional } \\
\text { hunting }\end{array}$ & \begin{tabular}{|l|}
$\begin{array}{l}\text { Inuktitut language } \\
\text { speakers }\end{array}$ \\
\end{tabular} & Polar bears & Lots of musicians \\
\hline $\begin{array}{l}\text { Training workshops and } \\
\text { courses }\end{array}$ & Seamstresses & \begin{tabular}{|l|} 
Young Hunters \\
Association
\end{tabular} & \begin{tabular}{|l|}
$\begin{array}{l}\text { Keeping the } \\
\text { environment } \\
\text { clean }\end{array}$ \\
\end{tabular} & Music festivals \\
\hline $\begin{array}{l}\text { Travelling out of country } \\
\text { (college etc) }\end{array}$ & & \begin{tabular}{|l} 
Food Bank and \\
Food Sharing
\end{tabular} & & $\begin{array}{l}\text { Fundraising and donations for } \\
\text { the needy }\end{array}$ \\
\hline $\begin{array}{l}\text { People participating in } \\
\text { church groups }\end{array}$ & & $\begin{array}{l}\text { Keeping our culture } \\
\text { and family }\end{array}$ & & \\
\hline $\begin{array}{l}\text { Good work performance } \\
\text { and ethic }\end{array}$ & & \begin{tabular}{|l} 
Experienced, expert \\
hunters
\end{tabular} & & \\
\hline $\begin{array}{l}\text { Increasing number of } \\
\text { small businesses }\end{array}$ & & $\begin{array}{l}\text { Culture of mutual } \\
\text { help and support }\end{array}$ & & \\
\hline \begin{tabular}{|l}
$\begin{array}{l}\text { Council, board, and } \\
\text { committees. MLA. }\end{array}$ \\
\end{tabular} & & Friendliness & & \\
\hline
\end{tabular}

Figure 2.5 Hughes, AK and Arviat, NU strengths.

The challenges expressed had many areas of intersection between Arviat, Nunavut and Hughes, Alaska.

a Cost of travel to and from the Arctic, both for personal and professional travel, and for shipping of needed goods and services, is clearly a factor of significant import. 
b High cost of food and necessary supplies for remote communities is also a constant consideration.

c The need to travel significant distances for certain health care is a clear concern.

d In terms of communication, Internet speeds and telecommunication were also at the top of most participants' minds. Limited bandwidth and the high cost of data were described in detail in both Nunavut and Alaska.

e While telephone (landline and cellular) connectivity was strong in Arviat, in Hughes especially the lack of cell towers coupled with landline connections prone to going out for extended periods of time caused connectivity issues that can directly impact the ability to communicate outside the community (both for personal and business purposes).

\section{Technology challenges}

The need for enhanced training and education in digital tools was another area of focus, in particular digital imaging/photographic skills were mentioned in both communities as sources of income for photographing artistic and creative works for sale, and in using for social media. Screen time was a concern in both communities with concerns expressed related to the culturally negative impact of some video games, movies and television not in-tune with traditional values. As a result, we had a number of discussions that emerged related to how digital tools were leading to a number of community

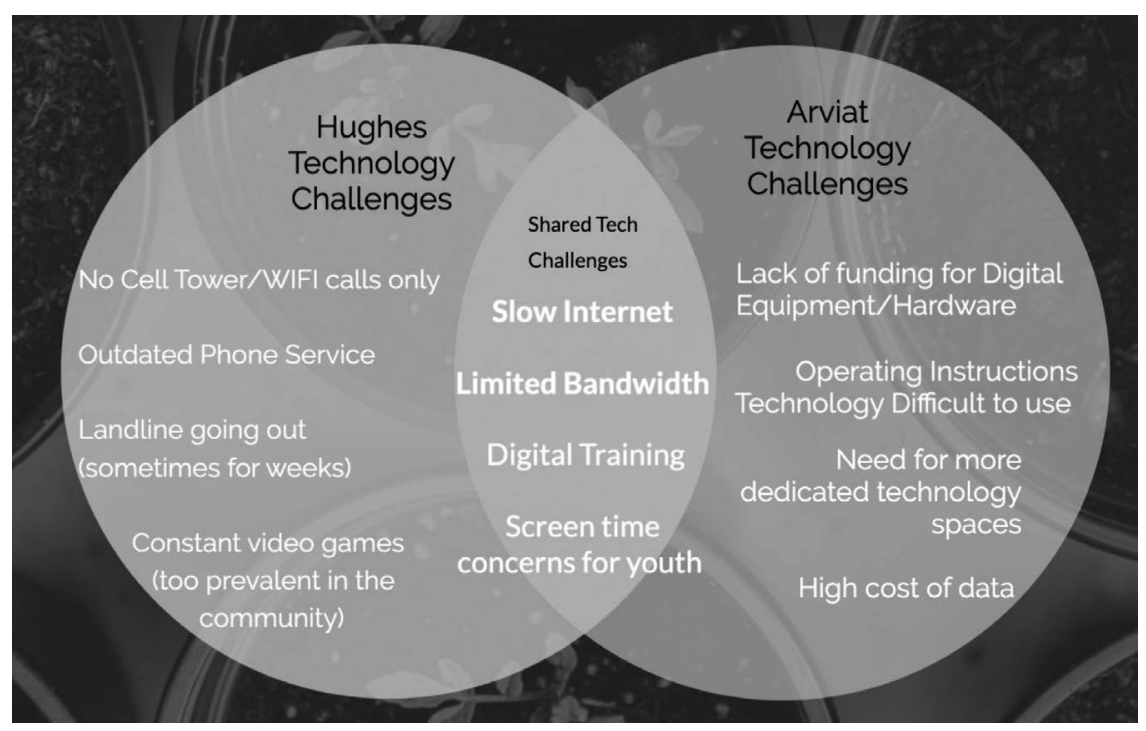

Figure 2.6 Venn diagram of hughes, $\mathrm{AK}$ and arviat, NU challenges. 
members never leaving their homes, with this impacting negatively on time spent with family, on the land, engaging in traditional activities, and in some cases causing loss of jobs or reducing motivation to engage socially.

\section{Housing challenges}

Additional challenges described in the United States and Canadian Arctic communities we visited also showed similarities across borders. A housing shortage is a critical factor across the North American Arctic and was described in detail by many individuals with whom the authors had the opportunity to speak.

"Housing is a major issue. Looking at the increasing number of children in town, where will they live?."

"A dire need is housing, overcrowding, societal problems. Overcrowding causes domestic violence, often there is not enough food for everyone in the same house, etc."

"The issue is still there. Why is this still happening when the rest of Canada and the US is so different?"

Housing has been expressed in multiple TCC community reports as one of the most pressing issues in rural Alaska. With recent budget cuts in the State there is concern regarding reduced housing construction and homelessness support (Kesslen, 2019; Restino, 2018).

\section{Drug and alcohol challenges}

Alcohol abuse was repeatedly described in discussions in both Nunavut and Alaska as a challenge so serious as to be a cross-generational crisis. In some communities in Alaska, as one resident stated, "the (corporations) had to separate the dividend out, divvy it out (in smaller sizes), because there would be too much crime like drug use and alcohol abuse when people received too much at once."

Bootleggers can make significant profits by bringing alcohol into dry communities in the Arctic. A fifth of alcohol $(750 \mathrm{ml})$ can sell for many hundreds of dollars. Bootleggers can allegedly do this regularly and often, in conversation we heard anecdotes of bootleggers who had regular businesses of bringing and shipping bottles into communities, resulting in significant negative social impacts caused to the communities. Links between alcohol (and other drugs) and suicide were also described as major issues in the North American Arctic that impacted the entire region significantly. Significant research well beyond the scope of this article investigates alcoholism and suicide in the Arctic (Brown, Dickerson, \& D'Amico, 2016; Ogilvie, 2018; Seyfrit et al., 1998; Skewes \& Blume, 2015; Wexler et al., 2015). 


\section{Food insecurity challenges}

Food insecurity was described as a major issue. This can take many forms including the extremely high costs of living in rural communities due to the greatly enhanced costs of shipping and transport, including the temptation of rural residents to purchase cheaper yet much less healthy options resulting in health concerns. One Arviat resident stated:

"Obviously we do not have highways, up here, everything has to be flown up here, and it's really expensive, and we do have sealift, but it only once a year, early summer, This is by water. What about fresh produce? Milk, or fruits and vegetables, you cannot ship them by sealift for the year, because obviously they have a short shelf life."

"We have no choice but to use air to bring in things like food, we need more road systems to assist with import(ation), however we are less than $1 \%$ of the voting members of Canada, we do not make enough of a difference to the big politicians."

"Within the federal level we do not have good representation from our cultural group. We need new members of parliament, senators. Again it goes back to the fact that we are too small, it's hard but that doesn't mean that we do nothing. One Inuit group on Facebook talking about food insecurity posted pictures of the high cost of food, and started a dialogue. They organized protests, and that kind of thing is good, and needed, and powerful. Even a small group on social media can have a significant impact in remote areas."

In Alaska, food insecurity is also an ongoing and serious issue that impacts quality of life and economic development equally. For Inuit and Alaska Natives traditional hunting and fishing for country food is a major source of needed nutrition that is often unavailable in store-bought goods (or is simply unaffordable). Global heating is observably impacting traditional hunting ranges and ability of Arctic residents to reach herds due to costs of gasoline and other necessary equipment to undertake long-distance expeditions (Baskin, 2016; Chapin \& Brinkman, 2016; Descamps et al., 2017; Koptseva \& Kirko, 2015; Poppel et al., 2015; Tse, Weiler, \& Kovesi, 2016).

\section{The challenges of discrimination, nepotism, and the "Arctic welfare trap"}

During conversations in communities in Alaska and Nunavut, the topic of economic nepotism and favoritism emerged regularly. Because communities can often be so small, issues of equitability and equal opportunities can quickly come to the forefront. In scholarly research issues of nepotism 
have been described in other circumpolar Arctic research (Gremaud, 2017; Russel, 2015; Sejersen, 2015; Wang, Degeorges, \& Forsvarsakademiet, 2014).

During one workshop discussion the following was mentioned:

"If you are part of the family you get the job. Some companies pre-hire before they even do interviews. They know that want this person, but they go through the procedure. That is really common in a lot of workplaces and companies. You are related to me, you are going to get hired."

As some businesses in Arctic Indigenous communities may be owned by non-natives, there was a sense in workshop discussions that native people in their own communities are often being passed by in favor of individuals living outside the Arctic who are flown in (at great expense) to do a job at very high contractor rates rather than training and growing local talent and expertise in order to support local sustainable economic development.

"They (non-natives) would rather hire their own families, from down south, than someone capable from town like an (Inuk, or Alaska Native) mechanic. Even if you have the qualification, even if you have the certificate, they want them because they are white and they think they know more. Even if you have the qualifications, there is a preconceived idea of this person as better compared to a local."

Inequities in access to health services were described including descriptions of time-delays in accessing healthcare for Indigenous peoples (as opposed to non-native people who were perceived as being seen immediately). Delays in law enforcement attention for natives as opposed to nonnatives were also described. Some quotes related to these aspects included:

"We have a story when the mother (who is Inuk) had to wait many months to get health care, but the qallunaat (non-inuk) got help immediately".

"Native people or people of color, if they are missing, you do not hear about them."

One aspect that arose during discussions related to concerns that Indigenous residents of the Arctic held as regards travel outside the Arctic, or into larger towns or cities where more non- Indigenous residents were present. These elements of discrimination and even fear were noted in both Nunavut and Alaska:

"It is scary. People look at you (outside of the Arctic), and they're like: 'she doesn't look white, she must be Native, Dene, Inuit."'

"It is dangerous to be down south with brown skin. Even when you are walking down the street, there are people who do not know your nationality, but they are like '(expletive) Indians, or just like 'savages"'. 
"It is especially bad, because you hear of these white people going missing, they are on the news 10 minutes later. But native people, you do not hear about it for 6 weeks, 2 months later, or maybe never. A white person, 10 minutes later they are on the news, amber alert".

Governmental welfare support in the Arctic was a topic that emerged on several occasions during workshop discussions. In some communities there was a sense expressed of the "welfare trap" or "welfare spiral" consisting of welfare resulting in a contraindication for willingness to start a small business or even commence new employment.

For some, the risk of starting a job, or creating a personally owned small business could result in the potential loss of welfare and an increase in the cost of housing that was far too great a risk to take. For this reason welfare was described by some as preferable to employment due to the regular income and reduced cost of housing. While future research into this phenomenon is certainly required it would seem that further governmental incentives for those interested in remote community small business development could be beneficial, so that a system designed to assist those in need would not be revoked for those who are taking the potentially significant risk of attempting to build their personal, local, and regional economies.

All of the issues described above are only a small fraction of the total challenges described. This section is not meant to be a comprehensive or exhaustive synopsis of challenges impacting Arctic sustainable entrepreneurship, but rather to serve as a brief and highly limited example of the scale and scope of issues that those living in the North American Arctic are encountering on a daily basis. If a resilient and sustainable North American economy beyond extractive resource economies is to be developed, it is incumbent that social issues be focused upon in tandem with culturally aligned entrepreneurial curricular and training elements in order to ensure healthy communities wherein enhanced business development may truly flourish with resilience.

\section{Unique opportunities}

\section{Digital entrepreneurial nomadic economies}

As a final step, in both our workshops and in individual interview in Arviat and Hughes, we asked participants about the unique opportunities they see for a digital creative economy in the Arctic.

One incredibly powerful motivator and mindset that was expressed by Indigenous residents of both Nunavut and Alaska during this fieldwork was that of the desirability of self-reliance, living off the land, with freedom to leave and return to town at will while sharing resources in community: a lifestyle that was indicated as being highly attractive to many among whom the authors discussed. This is also an entrepreneurial mindset: to use the 
resources available, and find solutions to problems while thriving in the harshest environments. Entrepreneurial definitions today look at the utilisation of scarce resources for the benefit of the community.

When the opportunity arose for participants in the Arviat workshop to travel onto the tundra to hunt and fish and spend time on the land, it was perceived by all with great anticipation. A number of participants indicated that this was the first time that they had had the opportunity to travel away from town in years. For others (Inuit residents born in the community), it was the very first time that they had ever gone on a hunting expedition. When a discussion began surrounding this issue, some comments included that:

"Access to travel on the land has become a luxury for the rich"

"We do not have access to our culture on the land because the cost of gasoline is so expensive".

"An ATV is over 10k, Snowmobiles up to $15 \mathrm{k}$. I can't afford it and I never leave town."

Connections between the traditional Indigenous nomadism of the past and the concept of digital nomadism of today were discussed in a hunting cabin near Maguse Lake, Nunavut. The concept discussed was that of possibilities for Inuit and other remote-region Arctic entrepreneurs living as digital nomads going back out on the land, using solar power for electrical power and leveraging (forthcoming) broadband digital connectivity outside of towns. This concept could incorporate digital currency transfer enabling payment to remote communities (including payments for services rendered on the land), and could enable digital Arctic nomadic entrepreneurs the possibility of conducting economic activity (possibilities mentioned included photography, drone filming/tracking of wildlife, videography, patterns for clothes, ecotourism, guiding, hunting, games and apps based on traditional knowledge, etc.).

The concept of digital nomadism exists in the research literature however often in terms of project-based. "Western professionals using a range of information systems (IS) and information technology (IT) tools to work digitally over the Internet while travelling perpetually" (Schlagwein, 2018). A number of articles describe the concept in terms of dissatisfied young urban digital workers constantly searching for more desirable, exotic locales within which to work (Jarrahi, 2019; Müller, 2016; Nash, 2018). The concept as it is being described in this writing however does not relate to attempting to wander in search of another locale to replace one's own, but rather to enable the full immersion in one's own born environment, in a sense to assist in reconnecting with the land/disconnecting from the colonial past which necessitated the loss of nomadic heritage due to residential schools, forced relocation, and other factors (Bombay, Matheson, \& Anisman, 2014; Dombrowski et al., 2016; Elias et al., 2012; Evans-Campbell, Walters, Pearson, \& Campbell, 2012; Felt, Procter, \& Natcher, 2012; Tester \& Kulchyski, 2011). 
Presently the resources necessary to enable culturally focused Arctic digital nomadic economic development are still lacking. Transportation (ATV/ Snowmobiles) still requires fossil-fuels, costs of which can be extremely high (and transport of which is extremely costly). Renewable power sources with reliable, strong batteries that can run vehicles (and function well in extremely cold temperatures) would be game-changers in the North. Power for small electronics is improving in terms of solar charging (GoalZero ${ }^{1}$ for example) however even beyond power sources, the key component of digital connectivity for cellular and data is greatly lacking outside of towns/hamlets. Iridium technology offers excellent solutions for connectivity (calling) and limited data (currently improving under the IridiumNEXT development) however the possibility of true satellite or terrestrial broadband could enable connectivity even in regions now considered disconnected.

Economic activities that could take place on the land are far-reaching in terms of possibilities. Eco-tourism is one area of great potential, providing sustainable experiences to tourists from across the world with a focus on environmental sustainability, stewardship and culturally guided/ values-driven locally owned initiatives. One of TakingItGlobal/Connected North's Digital Media Kits provided to some Arctic program participants consists of a MacBook Pro, a DJI Drone, a GoPro, a $360^{\circ}$ camera, Microphone, and iPhone. This kind of technology can generate an entire broad spectrum of potential economic activity able to be leveraged with adequate power, connectivity, and training

Culturally enhanced AirBnB experiences have generated interest in a number of communities in the North American Arctic in terms of ecotourism. Renee Linton of the Tanana Chiefs Conference has been spearheading initiatives related to a rural AirBnB Pilot Project designed to encourage entrepreneurism in interior Alaska TCC Ecotourism readiness surveys and village planning and development programs are designed to assess the suitability of ecotourism initiatives and alignment with community plans and tribal values (TCC, 2020). Some discussion during workshops centered around what would be needed in order to incentivise tourist travel to remote regions, and what would be viewed as "minimum necessities" in order to make ecotourism more attractive. Some of these necessities described included running water, electricity, communications (telephone and especially Internet connectivity), temperature control (heating and, increasingly cooling in summer months) and insect barriers among other factors. The potential possibility of allowing tourists to observe or even participate in some cultural events (only if approved by the communities) was mentioned as a possible incentive for increased ecotouristic activities. "Combining the AirBnB experience with cultural experiences, with beading, with country food, with participation in creating crafts" (Participant in Hughes, AK).

It should be mentioned that AirBnB is not meant here to serve as a utopian expression of ecotourism, but rather as one potential option for encouraging sustainable ecotourism in the Arctic. A number of research articles have 
described successful (and unsuccessful) attempts at leveraging this and other initiatives toward encouraging rural entrepreneurship, describing potential benefits but also challenges and concerns related to significant increases of tourism in rural circumpolar Arctic and other Indigenous regions (E. Henry, Newth, \& Spiller, 2017; Jæger, 2019; Koninx, 2018; Leeming, 2016; Müller, 2019; Outi et al., 2019; Sisneros-Kidd, Monz, Hausner, Schmidt, \& Clark, 2019; Spangler, 2018; Veijola \& Strauss-Mazzullo, 2019).

The interest in including art and traditional crafts into the ecotourism experience was expressed during workshop discussions: "When one does not know a lot about small businesses, it boils down to what we already know, culturally, it is our passion, what we like to do. For example, our art, jewelry making, or traditional art, if we market it well especially online, coupled with social media...before where you were so far from the marketplace, now that gap is now bridgeable due to the web."

In Hughes specifically, local residents who had made beautiful works of art had very little confidence in marketing these productions even though internet access was available. Taking high-quality images of the work was extremely helpful in terms of providing the best visibility and sale price possible for residents. Such training can be accomplished quite rapidly and can have measurable impacts in terms of financial takeaway.

\section{Conclusions and recommendations for further research}

The North American Arctic is entering into a unique yet tumultuous period where changes in environmental conditions coupled with extraordinarily increases in primarily extractive industries, are resulting in the exacerbation of significant social issues in Indigenous and other isolated communities in Alaska and Nunavut. Developing a value-based knowledge economy and providing an avenue for creative digital expression not simply for its own sake, but as a source of locally owned and operated economic development driving investment and national/international support, is potentially transformative economic activity for the future of the North American Arctic economy. Linkages between Nunavut and other Canadian Arctic territories with Alaska in terms of economic development hold potential for dynamic international circumpolar economic collaboration.

There is an extraordinarily untapped economic and social opportunity in facilitating North American Arctic Indigenous communities' efforts toward the development and application of their unique values, cultural traditional knowledge and expertise for the specific purpose of stimulating the knowledge economy in the North. Value-driven, community-centered digital creative industries focused on the unique environment of the North American Arctic, with collaborative hubs linking Alaska with Nunavut, Nunatsiavut, Nunavik and other regions, could result in the alleviation of a number of critical social issues currently hindering human and economic development in the Arctic. 
In order to fully enable resilient, sustainable economic development in the North American Arctic, it is incumbent upon Canada and the United States to comprehensively address the major social and infrastructural issues currently present in the North. Such investment can, this chapter argues, assist in the development of robust, sustainable, resilient and highly unique Arctic economies that will far outweigh the infrastructural and social commitments required.

\section{Acknowledgment}

This material is based upon work supported by the National Science Foundation under Grant No. 1758781 and Grant No. 1758814. Any opinions, findings, and conclusions or recommendations expressed in this material are those of the author(s) and do not necessarily reflect the views of the National Science Foundation.

\section{Note}

1. https://www.goalzero.com/story/

\section{References}

Alvarez, J., Yumashev, D., \& Whiteman, G. (2019). A framework for assessing the economic impacts of Arctic change. Ambio. doi: https://doi.org/10.1007/ s13280-019-01211-z.

Arctic Council. (n.d.). Observers. Arctic Council. https://arctic-council.org/index. php/en/about-us/arctic-council/observers

Avango, D., Nilsson, A. E., \& Roberts, P. (2013). Assessing Arctic futures: Voices, resources and governance. The Polar Journal, 3(2), 431-446. doi: https://doi.org/ 10.1080/2154896X.2013.790197.

Bakhshi, H., Freeman, A., \& Higgs, P. L. (2012). A dynamic mapping of the UK's creative industries. Retrieved from https://eprints.qut.edu.au/57251/

Barayamal (2016). Barayamal - Indigenous Entrepreneurship Australia. Barayamal. https://barayamal.com.au/

Baskin, M. (2016). Climate Change Related Impacts on Food Insecurity and Governance in the United States and Canadian Arctic (PhD Thesis). The George Washington University.

Bennett, M. M. (2016). Discursive, material, vertical, and extensive dimensions of post-Cold War Arctic resource extraction. Polar Geography, 39(4), 258-273. doi: https://doi.org/10.1080/1088937X.2016.1234517.

Bombay, A., Matheson, K., \& Anisman, H. (2014). The intergenerational effects of Indian Residential Schools: Implications for the concept of historical trauma. Transcultural Psychiatry, 51(3), 320-338.

Brown, R. A., Dickerson, D. L., \& D’Amico, E. J. (2016). Cultural identity among urban American Indian/Alaska native youth: Implications for alcohol and drug use. Prevention Science, 17(7), 852-861. doi: https://doi.org/10.1007/ s11121-016-0680-1. 
Bryson, J. M., \& Anderson, S. R. (2000). Applying large-group interaction methods in the planning and implementation of major change efforts. Public Administration Review, 60(2), 143-162. doi: https://doi.org/10.1111/0033-3352.00073.

Byers, M., \& Lodge, E. (2019). China and the northwest passage. Chinese Journal of International Law, 18(1), 57-90. doi: https://doi.org/10.1093/chinesejil/jmz001.

Caspary, G., \& O'Connor, D. (2003). Providing low-cost information technology access to rural communities in developing countries. https://www.oecd-ilibrary.org/ content/paper/675385036304

Castleden, H., Morgan, V. S., \& Lamb, C. (2012). "I spent the first year drinking tea": Exploring Canadian university researchers' perspectives on community-based participatory research involving Indigenous peoples. The Canadian Geographer/ Le Géographe Canadien, 56(2), 160-179.

Census Canada (2017). Population size and growth in Canada: Key results from the 2016 Census. (11), 14.

Chapin, T., \& Brinkman, T. J. (2016). Human adaptation responses to a rapidly changing Arctic: A research context for building system resilience. $A G U$ Fall Meeting Abstracts.

Christensen, N. B. (2003). Inuit in cyberspace: Embedding offline, identities online. https://books.google.com/books?id=9LfHN8xLILsC

Clement, A., Gurstein, M., Longford, G., Moll, M., \& Shade, L. R. (2012). Connecting Canadians: Investigations in community informatics. Athabasca University Press.

Comunian, R., Gilmore, A., \& Jacobi, S. (2015). Higher education and the creative economy: Creative graduates, knowledge transfer and regional impact debates. Geography Compass, 9(7), 371-383.

Cornik, K. (2016, October 31). An Ottawa millennial is changing lives and inspiring new businesses for Nunavut's youth. National Observer. https://www.nationalobserver. com/2016/10/31/news/ottawa-millennial-changing-lives-and-inspring-new-businessesnunavuts-youth

Dana, L. P., \& Anderson, R. B. (2007). International handbook of research on indigenous entrepreneurship. http://www.loc.gov/catdir/toc/fy0905/2006934134.html

National Congress of American Indians (NCAI). (2019). Data Disaggregation. NCAI. http://www.ncai.org/policy-research-center/research-data/data

Descamps, S., Aars, J., Fuglei, E., Kovacs, K. M., Lydersen, C., Pavlova, O., ... Strøm, H. (2017). Climate change impacts on wildlife in a high Arctic archipelago Svalbard, Norway. Global Change Biology, 23(2), 490-502.

Dixon, T. (2019). The role of social entrepreneurship and education in addressing native American social and economic challenges: A transformative study (Publication No. 13899185) [Doctoral Dissertation, University of Seattle]. ProQuest Dissertations Publishing. https://search.proquest.com/openview/2d2ba6f6f378dab8d13b58bd$58 \mathrm{f} 1 \mathrm{f} 64 \mathrm{~b} / 1$ ? pq-origsite $=$ gscholar $\& \mathrm{cbl}=18750 \&$ diss $=\mathrm{y}$

Dombrowski, K., Habecker, P., Gauthier, G. R., Khan, B., Moses, J., Arzyutov, D. V., \& Ween, G. (2016). Relocation redux: Labrador Inuit population movements and inequalities in the land claims era. Current Anthropology, 57(6).

Drewniak, M., Dalaklis, D., Kitada, M., Ölçer, A., \& Ballini, F. (2018). Geopolitics of Arctic shipping: The state of icebreakers and future needs. Polar Geography, 41(2), 107-125. doi: https://doi.org/10.1080/1088937X.2018.1455756.

Duisenberg, E. D. S. (Ed.). (2010). Creative economy report 2010: Creative economy: A feasible development option. Geneva: United Nations Conference on Trade and Development. 
Elias, B., Mignone, J., Hall, M., Hong, S. P., Hart, L., \& Sareen, J. (2012). Trauma and suicide behaviour histories among a Canadian indigenous population: An empirical exploration of the potential role of Canada's residential school system. Social Science \& Medicine, 74(10), 1560-1569.

Emmerson, C., \& Lahn, G. (2012, May 30). Arctic opening: Opportunity and risk in the high north [Monograph]. http://library.arcticportal.org/1671/

EntrepreNorth. (n.d.). Impact. EntrepreNorth. https://www.entreprenorth.ca/ impact.html

Ermine, W., Sinclair, R., \& Jeffery, B. (2004). The ethics of research involving Indigenous peoples. Saskatchewan: Indigenous Peoples' Health Research Centre Saskatoon.

Evans-Campbell, T., Walters, K. L., Pearson, C. R., \& Campbell, C. D. (2012). Indian boarding school experience, substance use, and mental health among urban two-spirit American Indian/Alaska natives. The American Journal of Drug and Alcohol Abuse, 38(5), 421-427.

Felt, L., Procter, A. H., \& Natcher, D. C. (2012). Settlement, subsistence, and change among the Labrador Inuit: The nunatsiavummiut experience (Vol. 2). Univ. of Manitoba Press.

Flew, T. (2011). The Creative Industries: Culture and Policy. Sage.

Florida, R. (2002). The rise of the creative class: And how it's transforming work, leisure, community and everyday life. Basic Books.

Florida, R. (2006). The flight of the creative class: The new global competition for talent. Liberal Education, 92(3), 22-29.

Geddert, J. S. (2019). Right of (northwest) passage: Toward a responsible Canadian Arctic sovereignty. Canadian Journal of Political Science/Revue Canadienne de Science Politique, 1-18. https://doi.org/10.1017/S0008423919000052

Giles, B. D. (2003). The Earth is faster now: Indigenous observations of Arctic environment change, edited by Igor Krupnik and Dyanna Jolly. Arctic Research Consortium of the United States, Fairbanks, Alaska, 2002. No. of pages: xxviii + 356. ISBN 0-9 720 449-0-6. International Journal of Climatology, 23(10), 1265-1265. https://doi.org/10.1002/joc.936

Graham, M., Hjorth, I., \& Lehdonvirta, V. (2017). Digital labour and development: Impacts of global digital labour platforms and the gig economy on worker livelihoods. Transfer: European Review of Labour and Research, 23(2), 135-162. doi: https://doi.org/10.1177/1024258916687250.

Gremaud, A.-S. N. (2017). Icelandic futures: Arctic dreams and geographies of crisis. In L.-A. Körber, S. MacKenzie, \& A. Westerståhl Stenport (Eds.), Arctic environmental modernities: From the age of polar exploration to the era of the anthropocene (pp. 197-213). https://doi.org/10.1007/978-3-319-39116-8_12

Hagoort, G. (2003). Art management: Entrepreneurial style. https://books.google. $\mathrm{com} /$ books?id=qgAqlvxxYgQC

Harris, C., Collins, M., \& Cheek, D. (2013). America's creative economy: A study of recent conceptions, definitions, and approaches to measurements across the USA. Oklahoma City: National Creativity Network.

Heinsius, J., \& Lehikoinen, K. (2013). Training Artists for Innovation: Competencies for New Contexts.

Henry, C. (2019). Canadian government pledges \$521 million for Telesat LEO constellation. SpaceNews. https://spacenews.com/canadian-government-pledges521-million-for-telesat-leo-constellation/ 
Henry, E., Newth, J., \& Spiller, C. (2017). Emancipatory indigenous social innovation: Shifting power through culture and technology. Journal of Management \& Organization, 23(6), 786-802. doi: https://doi.org/10.1017/jmo.2017.64.

Hudson, H. E. (2011). Digital diversity: Broadband and indigenous populations in Alaska. Journal of Information Policy, 1, 378-393. https://doi.org/10.5325/ jinfopoli.1.2011.0378

Huggan, G., \& Jensen, L. (2016). Postcolonial perspectives on the European high North: Unscrambling the Arctic. Springer.

Hutchins, R. M. (1947). By the commission on freedom of the press. A free and responsible press: A general report on mass communication: Newspapers, radio, motion pictures, magazines and books... [Foreword by Robert M. Hutchins.]. University of Chicago Press.

Innovation, Science and Economic Development Canada. (2019). High-Speed Access for All: Canada's Connectivity Strategy. https://www.ic.gc.ca/eic/site/139. nsf/eng/h_00002.html

Inspire Nunavut. (n.d.). Inspire Nunavut. Inspire Nunavut. https://www.inspirenunavut. com

Jæger, K. (2019). Tourists and Communities in Rural Festival Encounters: A mutually beneficial relationship?. https://uis.brage.unit.no/uis-xmlui/handle/11250/2593180

Jarrahi, M. H. (2019). Personalization of knowledge, personal knowledge ecology, and digital nomadism. Journal of the Association for Information Science and Technology, 70(4), 313-324.

Jensen, L. (2015). Greenland, Arctic orientalism and the search for definitions of a contemporary postcolonial geography. KULT. Postkolonial Temaserie, 12, 139-153.

Johnston, M., Dawson, J., \& Stewart, E. (2019). Marine tourism in Nunavut: Issues and opportunities for economic development in Arctic Canada. In R. L. Koster $\&$ D. A. Carson (Eds.), Perspectives on rural tourism geographies: Case studies from developed nations on the exotic, the fringe and the boring bits in between (pp. 115-136). https://doi.org/10.1007/978-3-030-11950-8_7

Keil, K., \& Knecht, S. (2017). Governing Arctic change: Global perspectives. Palgrave Macmillan.

Kesslen, B. (2019). Homeless services in Alaska face uncertain future as state cuts back. $N B C$ News. https://www.nbcnews.com/news/us-news/death-sentence-homelessservices-alaska-face-uncertain-future-state-cuts-n1057021

Knaapila, A.-J. (2019). Arctic Telecom. Cinia. https://www.cinia.fi/en/archive/ arctic-telecom-cable-initiative-takes-major-step-forward.html

Koivurova, T. (2018). China and the Development of International Law on Arctic Shipping: Challenges and Opportunities (SSRN Scholarly Paper No. ID 3115830). Social Science Research Network. https://papers.ssrn.com/abstract=3115830

Koninx, F. (2018). Ecotourism and rewilding: The case of Swedish lapland. Journal of Ecotourism, O(0), 1-16. doi: https://doi.org/10.1080/14724049.2018.1538227.

Kooyman, R. (Ed.). (2011). The entrepreneurial dimension of the cultural and creative industries. Hogeschool vor den Kunsten (HKU).

Koptseva, N. P., \& Kirko, V. I. (2015). The impact of global transformations on the processes of regional and ethnic identity of indigenous peoples Siberian Arctic. Mediterranean Journal of Social Sciences, 6(3 S5), 217.

Kuersten, A. (2018). The Arctic digital divide. In B. O’Donnell, M. Gruenig, \& A. Riedel (Eds.), Arctic summer college yearbook: An interdisciplinary look into Arctic sustainable development (pp. 93-105). https://doi.org/10.1007/978-3-319-66459-0_8 
Kukutai, T., \& Taylor, J. (Series Ed.). (2016). Indigenous Data Sovereignty (Vol. 38). http://www.jstor.org/stable/j.ctt1q1crgf

Lajeunesse, A., \& Huebert, R. (2019). Preparing for the next Arctic sovereignty crisis: The northwest passage in the age of Donald Trump. International Journal, 74(2), 225-239. doi: https://doi.org/10.1177/0020702019849641.

Lalonde, S. (2018). Canada's Influence on the Law of the Sea. (7), 26.

Landzelius, K. (Ed.). (2006). Native on the net: Indigenous and diasporic peoples in the virtual age (1 edition). Routledge.

Launch Alaska. (2019). Fall 2019. Launch Alaska. http://www.launchalaska.com/ fall-19

Lee, C. W., McQuarrie, M., \& Walker, E. T. (2015). Democratizing inequalities: Dilemmas of the new public participation. NYU Press.

Leeming, J. (2016). Addressing Cultural Vulnerabilities in Arctic Tourism: Kindness as "Third Space." https://uwspace.uwaterloo.ca/handle/10012/10878

Leung, W.-F. (2019). Cool, creative, but not so equal. In W.-F. Leung (Ed.), Digital entrepreneurship, gender and intersectionality: An East Asian perspective (pp. 161-196). https://doi.org/10.1007/978-3-319-97523-8_5

Levinson-King, R. (2019, September 9). The superpower fight for internet near the Arctic. BBC News. https://www.bbc.com/news/world-us-canada-49415867

Liu, N. (2019). China's Arctic policy and belt and road initiative: Synergy or conflict? The Yearbook of Polar Law Online, 10(1), 431-434. doi: https://doi. org/10.1163/22116427_010010020.

Louis, R. P. (2007). Can you hear us now? Voices from the margin: Using indigenous methodologies in geographic research. Geographical Research, 45(2), 130-139.

Markusen, A., \& Gadwa, A. (2010). Arts and culture in urban or regional planning: A review and research agenda. Journal of Planning Education and Research, 29(3), 379-391.

McMahon, R., Gurstein, M., Beaton, B., O’Donnell, S., \& Whiteduck, T. (2014). Making information technologies work at the end of the road. Journal of Information Policy, 4, 250-269. https://doi.org/10.5325/jinfopoli.4.2014.0250

Meeker, M., \& Wu, L. (2018). Internet trends 2018. Kleiner Perkins.

Müller, A. (2016). The digital nomad: Buzzword or research category? Transnational Social Review, 6(3), 344-348.

Müller, D. K. (2019). A research agenda for tourism geographies. Edward Elgar Publishing.

Nash, C. (2018). Digital nomads beyond the buzzword: Defining digital nomadic work and use of digital technologies. International Conference on Information (pp. 207-217). Springer.

Murphy, A. (2018, December 6). Native Heroes Take Center Stage at Indigenous Comic Con. PBS. https://www.pbs.org/native-america/blogs/native-voices/nativeheroes-take-center-stage-at-indigenous-comic-con/

Naudin, A. (2017). Cultural Entrepreneurship: The Cultural Worker's Experience of Entrepreneurship. https://books.google.com/books?id=ujQ8DwAAQBAJ

Navigating the North - Innovation Summit 2019. (n.d.). Retrieved September 30, 2019, from http://www.navnorthsummit.com/

Nelson, J. (2017). Getting to the Bottom of Top: Foundations of the Methodologies of the Technology of Participation. https://books.google.com/books?id=CuNFDwAAQBAJ

Nicholls, R. (2009). Research and indigenous participation: Critical reflexive methods. International Journal of Social Research Methodology, 12(2), 117-126. 
Nong, D., Countryman, A. M., \& Warziniack, T. (2018). Potential impacts of expanded Arctic Alaska energy Resource extraction on US energy sectors. Energy Policy, 119, 574-584. https://doi.org/10.1016/j.enpol.2018.05.003

Oakley, K. (2004). Not so cool britannia the role of the creative industries in economic development. International Journal of Cultural Studies, 7(1), 67-77.

Ogilvie, K. A. (2018). Unintended consequences of local alcohol restrictions in rural Alaska. Journal of Ethnicity in Substance Abuse, 17(1), 16-31.

Outi, R., de la B., Suzanne, Brynhild, G., Pór, J., Gunnar, K, M., Dieter, Jarkko, S., ... Maaria, N. (2019). Arctic tourism in times of change: Seasonality. Nordic Council of Ministers.

Pasch, T., Bjerklie, D., \& Trahant, M. (2016). Arctic IDEA: Nunavut Broadband and digital entrepreneurialism. Presented at the ArcticNet Annual Scientific Meeting, Winnipeg, MB, Canada.

Pasch, T. J. (2015). Towards the enhancement of Arctic digital industries: "Translating” cultural content to new media platforms.

Patvardhan, V. S. (1990). Growth of indigenous entrepreneurship. Bombay: Popular Prakashan. (4848136).

Petrov, A. N. (2017). Human capital and sustainable development in the Arctic: Towards intellectual and empirical framing. In G. Fondahl \& G. N. Wilson (Eds.), Northern Sustainabilities: Understanding and addressing change in the circumpolar world (pp. 203-220). https://doi.org/10.1007/978-3-319-46150-2_16

Philip, L., \& Williams, F. (2019). Remote rural home based businesses and digital inequalities: Understanding needs and expectations in a digitally underserved community. Journal of Rural Studies, 68, 306-318. https://doi.org/10.1016/j.jrurstud. 2018.09.011

Pinto, L. E., \& Blue, L. E. (2016). Pushing the entrepreneurial prodigy: Canadian Aboriginal entrepreneurship education initiatives. Critical Studies in Education, 57(3), 358-375. doi: https://doi.org/10.1080/17508487.2015.1096291.

Poppel, B., Flaegteborg, M., Siegstad, M. O., \& Snyder, H. T. (2015). The Arctic as a "Hotspot" for natural Resource extraction and global warming. The Economy of the North, 129-135.

Quassa, P. A. (2018, February). Proceedings of the Special Senate Committee on the Arctic. Proceedings of the Special Senate Committee on the Arctic. Ottawa. https:// sencanada.ca/en/Content/Sen/Committee/421/ARCT/03ev-53837-e

Restino, C. (2018). Housing shortage in rural Alaska must be met with comprehensive solution. The Arctic Sounder. http://www.thearcticsounder.com/ article/1835housing_shortage_in_rural_alaska_must_be_met

Restrepo, F. B., \& Marquez, I. D. (2013). The Orange economy: An infinite opportunity. Washington, D.C: Inter-American Development Bank.

Roberts, E., \& Townsend, L. (2016). The contribution of the creative economy to the resilience of rural communities: Exploring cultural and digital capital. Sociologia Ruralis, 56(2), 197-219. https://doi.org/10.1111/soru.12075

Rodon, T., \& Lévesque, F. (2015). Understanding the social and economic impacts of mining development in inuit communities: Experiences with past and present mines in inuit nunangat. Northern Review, (41), 13-39.

Romero Manrique, D., Corral, S., \& Guimarães Pereira, Â. (2018). Climate-related displacements of coastal communities in the Arctic: Engaging traditional knowledge in adaptation strategies and policies. Environmental Science \& Policy, 85, 90-100. https://doi.org/10.1016/j.envsci.2018.04.007 
Röschenthaler, U., \& Schulz, D. (2015). Cultural Entrepreneurship in Africa. https:// books.google.com/books?id=z4_4CgAAQBAJ

Russel, G. (2015). Canadian Arctic Policy and Program Development and Inuit Recognition: A Neoliberal Governmentality Analysis of Canada's Northern Strategy and "The Missing Piece" [Doctoral Thesis, University of Toronto]. University of Toronto TSpace. https://tspace.library.utoronto.ca/handle/1807/69754

Salemink, K., Strijker, D., \& Bosworth, G. (2017). Rural development in the digital age: A systematic literature review on unequal ICT availability, adoption, and use in rural areas. Journal of Rural Studies, 54, 360-371. https://doi.org/10.1016/j. jrurstud.2015.09.001

Schlagwein, D. (2018). "Escaping the rat race": Justifications in digital nomadism. ECIS, 31.

Sejersen, F. (2015). Rethinking Greenland and the Arctic in the era of climate change: New northern horizons. Routledge.

Canada, S. of. (2019, June 10). Senate of Canada - Northern Lights: A wake-up call for the future of Canada. Senate of Canada. https://sencanada.ca/en/info-page/ parl-42-1/arct-northern-lights/

Seyfrit, C. L., Hamilton, L. C., Duncan, C. M., \& Grimes, J. (1998). Ethnic identity and aspirations among rural Alaska youth. Sociological Perspectives, 41(2), 343-365. doi: https://doi.org/10.2307/1389481.

Shadian, J. D. (2018). The Emerging Economy of the North American Arctic. Arctic360, 9.

Simón, Y. (2016, July 22). The First-Ever Indigenous Comic Con Puts Native Artists in the Spotlight. Remezcla. https://remezcla.com/features/culture/this-comicconvention-aims-to-put-indigenous-art-and-pop-culture-in-dialogue/

Sisneros-Kidd, A. M., Monz, C., Hausner, V., Schmidt, J., \& Clark, D. (2019). Nature-based tourism, resource dependence, and resilience of Arctic communities: Framing complex issues in a changing environment. Journal of Sustainable Tourism, 27(8), 1259-1276. doi: https://doi.org/10.1080/09669582.2019.1612905.

Skewes, M. C., \& Blume, A. W. (2015). Ethnic identity, drinking motives, and alcohol consequences among Alaska native and non-native college students. Journal of Ethnicity in Substance Abuse, 14(1), 12-28.

Smith, L. C. (2010). The world in 2050: Four forces shaping civilization's northern future. Dutton.

Sorin, G. S., \& Sessions, L. A. (2015). Case studies in cultural entrepreneurship: How to create relevant and sustainable Institutions. Lanham: Rowman \& Littlefield.

Spangler, I. (2018). "ONE MORE WAY TO SELL NEW ORLEANS": Airbnb and the commodification of authenticity through local emotional labor. Theses and Dissertations-Geography. https://doi.org/10.13023/etd.2018.241

Spencer, L. J. (1989). Winning through participation: Meeting the challenge of corporate change with the technology of participation. Kendall/Hunt Pub. Co. (3874708).

Stein, D. (2018). Protecting the Arctic environment from northwest passage shipping in the era of climate change drinking water issue: Center for environmental law prize winning comment. Tulane Environmental Law Journal, (2), 239-256.

Stephen, K. (2018). Societal impacts of a rapidly changing Arctic. Current Climate Change Reports, 4(3), 223-237. doi: https://doi.org/10.1007/s40641-018-0106-1.

Stroeve, J.C., Mioduszewski, J.R., Rennermalm, A., Boisvert, L.N., Tedesco, M., Robinson, D. (2017). Investigating the local-scale influence of sea ice on Greenland surface melt. The Cryosphere, 11(5), 2363-2381. doi: https://doi.org/10.5194/tc-11-2363-2017. 
Sum, N.-L., \& Jessop, B. (2013). Competitiveness, the knowledge-based economy and higher education. Journal of the Knowledge Economy, 4(1), 24-44. doi: https:// doi.org/10.1007/s13132-012-0121-8.

Tanana Chiefs Conference (TCC). (2019). Tanana Chiefs Conference. TCC. https:// www.tananachiefs.org/

Tanana Chiefs Conference (TCC). (2020). Village Planning \& Grant Writing. TCC. https://www.tananachiefs.org/services/village-planning-grant-writing/

Tester, F., \& Kulchyski, P. (2011). Tammarniit (mistakes): Inuit relocation in the Eastern Arctic, 1939-63. UBC press.

Tol, R. S. J. (2009). The economic effects of climate change. Journal of Economic Perspectives, 23(2), 29-51.

Tse, S. M., Weiler, H., \& Kovesi, T. (2016). Food insecurity, vitamin d insufficiency and respiratory infections among inuit children. International Journal of Circumpolar Health, 75(1), 29954.

United Nations Educational, Scientific and Cultural Organization (UNESCO). (2013). Creative Economy Report 2013 Special Edition: Widening Local Development Pathways. http://www.unesco.org/culture/pdf/creative-economyreport-2013.pdf

Veijola, S., \& Strauss-Mazzullo, H. (2019). Tourism at the crossroads of contesting paradigms of Arctic development. In M. Finger \& L. Heininen (Eds.), The global Arctic handbook (pp. 63-81). https://doi.org/10.1007/978-3-319-91995-9_5

Wang, N., Degeorges, D., \& Forsvarsakademiet. (2014). Greenland and the new Arctic: Political And security implications of a statebuilding project. RDDC Publishing House.

Wang, X., Jiang, D., \& Lang, X. (2017). Future extreme climate changes linked to global warming intensity. Science Bulletin, 62(24), 1673-1680. doi: https://doi. org/10.1016/j.scib.2017.11.004.

Warwick, M. (2019, September 5). It's not so grim up North as fast Internet reaches the Arctic. TelecomTV. https://www.telecomtv.com/content/satellite/ its-not-so-grim-up-north-as-fast-internet-reaches-the-arctic-36235/

Weber-Pillwax, C. (2004). Indigenous researchers and indigenous research methods: Cultural influences or cultural determinants of research methods. Pimatisiwin: A Journal of Aboriginal \& Indigenous Community Health, 2(1).

Wexler, L., Chandler, M., Gone, J. P., Cwik, M., Kirmayer, L. J., LaFromboise, T., \& Allen, J. (2015). Advancing suicide prevention research with rural American Indian and Alaska native populations. American Journal of Public Health, 105(5), 891-899.

World Economic Forum (2015). Arctic Investment Protocol: Guidelines for Responsible Investment in the Arctic. Global Agenda Council on the Arctic. http://www3.weforum.org/docs/WEF_Arctic_Investment_Protocol.pdf

Wuttunee, W. (2004). Living rhythms: Lessons in aboriginal economic resilience and vision. McGill-Queen's Press - MQUP.

Young, J. C. (2019). The new knowledge politics of digital colonialism. Environment and Planning A: Economy and Space, 51(7), 1424-1441. doi: https://doi.org/10.1177/ $0308518 X 19858998$.

Young, J. C. (2017). Encounters Across Difference: The Digital Geographies of Inuit, the Arctic, and Environmental Management [Doctoral dissertation, University of Washington]. Semantic Scholar. 